\title{
PENGALIRAN AIR LIMBAH DI DAERAH PEMUKIMAN
}

Henita Rahmayanti

\begin{abstract}
Abstrak
Dalam kegiatan manusia selalu akan menghasilkan limbah baik berupa limbah cair maupun padat, tentunya perlu pengelolaan yang baik agar tidak berakibat tidak baik bagi lingkungan.

Pengaliran air limbah di daerah pemukiman mutlak diperlukan, dalam pengelolaan yang diupayakan dengan sebaik-baiknya sesuai dengan ketentuan yang ada agar kualitas kesehatan lingkungan pemukinan dapat dipenuhi.
\end{abstract}

Kata Kunci : air limbah, pemukiman, kesehatan lingkungan

\section{Pendahuluan}

Air limbah adalah hasil buangan dari rumah tangga, industri, yang merupakan air hasil kegiatan yang tidak berguna lagi, maka diperlukan suatu pengolahan yang baik. Apabila sistem pengolahan ini tidak dilakukan dengan baik maka akan banyak menimbulkan banyak masalah.

Air limbah rumah tangga merupakan limbah yang paling banyak dihasilkan pada daerah pemukiman.

Kandungan bahan kimia yang ada dalam air limbah dapat merugikan lingkungan dengan berbagai cara. Bahan organik terlarut dapat menghabiskan oksigen dalam limbah serta akan menimbulkan bau yang tidak sedap pada penyediaan air bersih.

Air limbah dengan pengotoran yang sedang, sekitar $75 \%$ dari benda yang tercampur dan $40 \%$ dari zat padat yang dapat disaring adalah berupa bahan organik alami. Zat padat tersebut adalah bagian dari kelompok binatang dan tumbuh-tumbuhan serta hasil kegiatan manusia yang berhubungan dengan komponen bahan organik tiruan, berisikan kombinasi dari karbon, hidrogen, dan oksigen bersama nitrogen.

Pada umumnya kandungan organik yang dijumpai dalam air limbah berisikan 40-60 \% adalah protein, 25-50 \% karbohidrat serta $10 \%$ berupa lemak/minyak. Urea sebagai kandungan bahan terbanyak di dalam urine 
merupakan bagian lain yang penting dalam bahan organik. Sehingga pengaliran yang baik dari air limbah dirasa sangat diperlukan pada suatu daerah agar kualitas lingkungannya dapat dijaga dengan baik.

\section{Pembahasan}

\section{Air Limbah dan Masalah yang Dapat Ditimbulkan}

Beberapa istilah yang sering digunakan dalam pengolahan air limbah :

Kotoran rumah tangga (domestic sewage) adalah air yang telah dipergunakan yang berasal dari rumah tangga atau pemukiman termasuk di dalamnya adalah yang berasal dari kamar mandi, WC, serta tempat memasak.

Air limbah (waste water) adalah kotoran dari masyarakat dan rumah tangga dan juga yang berasal dari industri, air tanah, air permukaan, serta buangan lainnya dengan demikian air buangan ini merupakan hal yang bersifat kotoran umum.

Saluran air limbah (sewer) adalah perlengkapan pengelolaan air limbah, bisa berupa pipa ataupun selokan yang dipergunakan untuk membawa air buangan dari sumbernya sampai ke tempat pengelolaan atau tempat pembuangan.

Saluran tercampur (combined sewer) adalah saluran air limbah yang dipergunakan untuk mengalirkan air limbah, baik yang berasal dari rumah tangga maupun yang berasal dari daerah industri, air hujan dan air permukaan.

Saluran terpisah (separate sewer) adalah cara pembuangan air limbah dengan cara mengadakan pemisahan antara air limbah yang berasal dari rumah tangga atau daerah pemukiman dan air limbah yang berasal dari daerah industri dengan limbah yang berasal dari daerah luapan air hujan atau dari aliran pengeringan.

Pembuangan sistem saluran (sewerage) adalah cara pengolahan air limbah termasuk di dalamnya mulai dari pengumpulan, pemompaan, proses pengaliran sampai pada proses pengolahannya.

Lubang pemeriksaan (man hole) adalah lubang yang diletakkan di atas saluran yang menghubungkan saluran dengan udara terbuka.

Pengaliran Air Limbah Di Daerah Pemukiman (Henita Rahmayanti, Dosen Jurusan Teknik Sipil FT- UNJ) 


\section{Sumber Asal Air Limbah}

Sumber utama air limbah rumah tangga di kota Jakarta yaitu berasal dari perumahan dan daerah perdagangan. Adapun sumber lainnya yang tidak kalah pentingnya adalah daerah perkantoran atau lembaga serta daerah fasilitas rekreasi. Untuk daerah tertentu banyaknya air limbah dapat diukur secara langsung.

Untuk daerah perumahan aliran air limbah biasanya diperhitungkan melalui kepadatan penduduk dan rata-rata perorang dalam membuang air limbah. Adapun besarnya rata-rata air limbah yang berasal dari pemukiman dapat dilihat dalam tabel 1.

Tabel 1. Rata-rata Aliran Air Limbah dari Daerah Pemukiman

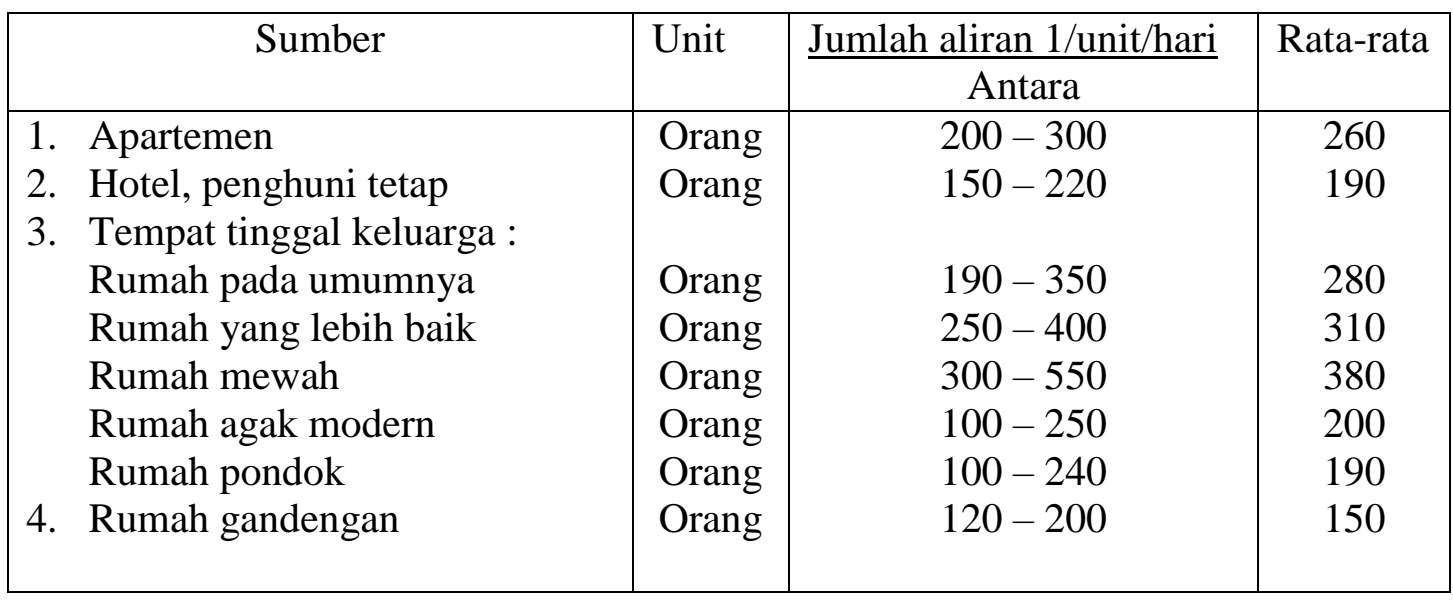

Sumber : Dasar-dasar Pengolahan Air Limbah, Sugiharto

Apabila turun hujan di suatu daerah, maka air yang turun secara cepat mengalir masuk ke dalam saluran pengering atau saluran air hujan. Apabila ini tidak mampu menampung, maka limpahan air hujan akan digabung dengan saluran air buangan/ air limbah, dengan demikian akan merupakan tambahan yang sangat besar. Oleh karena itu, perlu diketahui curah hujan yang ada sehingga banyaknya air yang akan ditampung melalui saluran air hujan atau saluran pengering dan saluran air limbah dapat diperhitungkan.

\section{Komposisi Air Buangan/Air Limbah}

Sesuai dengan sumber asalnya, maka air limbah mempunyai komposisi yang sangat bervariasi dari setiap tempat dan setiap saat. Akan tetapi, secara garis besar zat-zat yang terdapat dalam limbah dapat dikelompokkan seperti 
pada skema berikut ini.

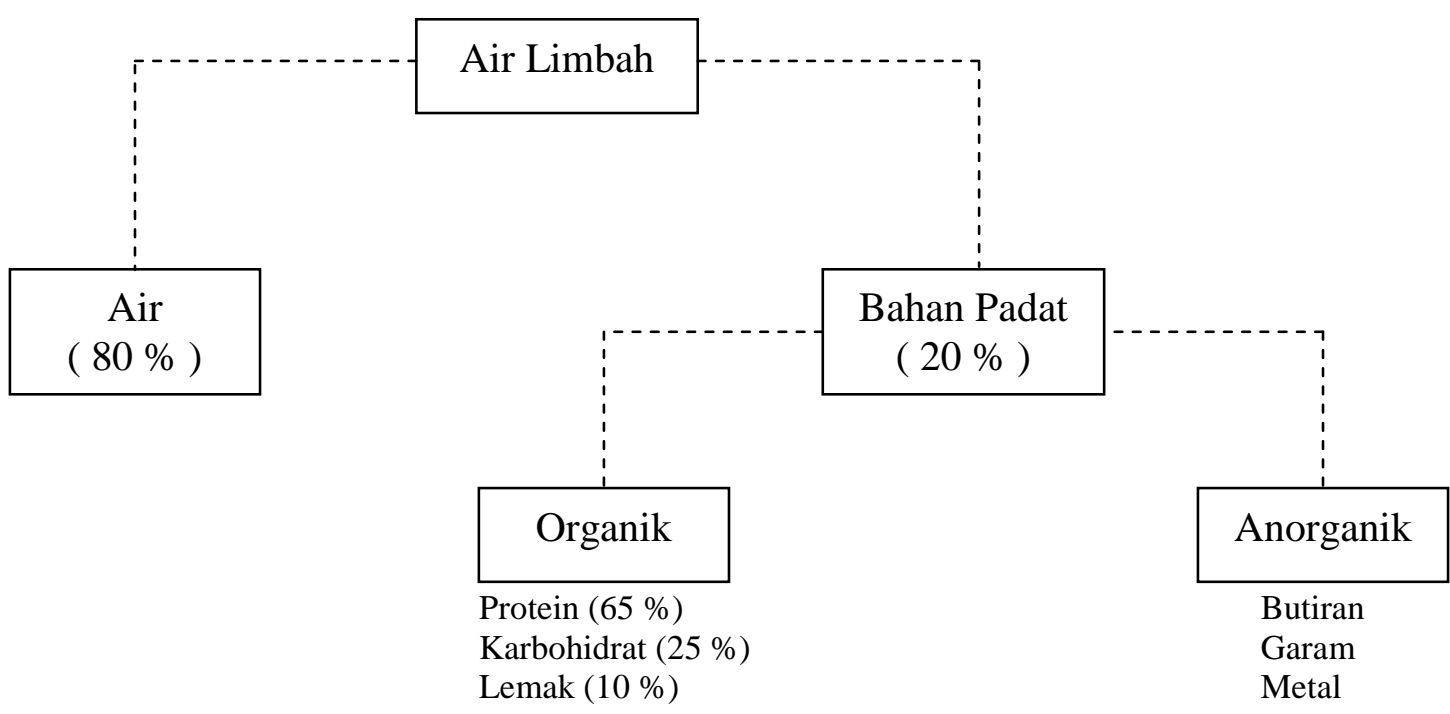

Sumber : Dasar-dasar Pengolahan Air Limbah, Sugiharto

\section{Efek Buruk Air Limbah}

1. Gangguan Terhadap Kesehatan

Air limbah sangat berbahaya terhadap kesehatan manusia mengingat bahwa banyak penyakit yang dapat ditularkan melalui air limbah. Air limbah ini ada yang hanya berfungsi sebagai media pembawa saja seperti penyakit kolera, radang usus, hepatisis. Selain sebagai pembawa penyakit di dalam air limbah itu sendiri banyak terdapat bakteri patogen penyebab penyakit seperti:

\section{Vibrio Kolera}

Menyebabkan penyakit kolera asiatika dengan penyebaran utama melalui air limbah yang telah tercemar oleh kotoran manusia.

\section{Salmonella Typhosa}

Merupakan penyebab tiphus abdominalis dan para tiphus yang banyak terdapat di dalam air limbah bila terjadi wabah.

\section{Shigella Spp}

Adalah penyakit disentri bacsillair banyak terdapat pada air yang tercemar. Adapun penularan adalah melalui kontak langsung dengan kotoran manusia ataupun melalui perantara makanan, lalat, dan tanah.

Pengaliran Air Limbah Di Daerah Pemukiman (Henita Rahmayanti, Dosen Jurusan Teknik Sipil FT- UNJ) 


\section{Leptospira}

Adalah penyebab penyakit weil dengan penularan utama berasal dari tikus selokan.

\section{Taenia Spp}

Adalah penyebab penyakit cacing pita, dengan kondisi yang sangat tahan terhadap cuaca.

\section{Askaris Spp. Enterobius Spp}

Menyebabkan penyakit cacingan dan terdapat pada air hasil pengolahan dan lumpur.

2. Gangguan terhadap Kehidupan Biotik

Dengan banyaknya zat pencemar yang ada di dalam air limbah, maka akan menyebabkan menurunnya akadar oksigen yang terlarut dalam air limbah. Hal ini akan menyebabkan kehidupan dalam air yang membutuhkan oksigen akan terganggu, mengurangi kehidupan biota air.

3. Gangguan terhadap Keindahan

Dengan semakin banyaknya zat organik yang dibuang oleh rumah tangga maka setiap hari akan dihasilkan air limbah yang berupa bahanbahan organik dalam jumlah yang sangat besar. Selama waktu tertentu maka air limbah mengalami pembusukan dari zat organik yang ada di dalamnya. Sebagai akibat selanjutnya adalah timbulnya bau hasil pengurangan zat organik yang sangat menusuk.

Disamping bau yang ditimbulkan, maka dengan menumpuknya ampas akan memerlukan tempat yang banyak dan mengganggu keindahan tempat disekitarnya.

4. Gangguan terhadap Kerusakan Benda

Apabila air limbah mengandung gas karbondioksida yang agresif, maka mau tidak mau akan mempercepat proses terjadi karat pada benda yang terbuat dari besi. Dengan rusaknya benda tersebut maka biaya pemeliharaannya akan semakin besar, yang berarti menimbulkan kerugian material.

\section{Pengaliran Air Limbah di Daerah Perkotaan dan Permasalahannya}

Susunan dan sifat air limbah yang berasal dari daerah pemukiman dan industri adalah bervariasi tergantung dari macam dan jenisnya. Agar limbah dapat dikelola dengan baik maka susunan dan sifat air limbah tidak dapat

MENARA, JURNAL TEKNIK SIPIL VOL. I, NO. 2 JULI 2006: 237-246 
diabaikan, karena hal ini akan menyulitkan pada saat pengaliran atau saat pengolahannya.

Selain itu benda-benda yang melayang dan mudah mengendap dapat menyulitkan dan dapat mengganggu proses pembersihan. Oleh karenanya pembuatan saluran air limbah seharusnya diperhitungkan agar semua benda yang berada di dalam air limbah dapat mengalir secara terus menerus dan menghindarkan benda di dalam air limbah menempel pada saluran. Untuk menjaga tidak terjadinya pengendapan, maka percepatan aliran diatur berdasarkan pertimbangan berikut ini:

1. Untuk membawa lumpur kecepatan aliran sebesar $0,1 \mathrm{~m}^{3} /$ detik.

2. Untuk membawa pasir halus kecepatan aliran sebesar $0,15 \mathrm{~m}^{3} /$ detik.

3. Untuk membawa pasir kasar kecepatan aliran sebesar $0,2 \mathrm{~m}^{3} /$ detik

4. Untuk membawa kerikil kecepatan aliran sebesar $0,3 \mathrm{~m}^{3} /$ detik

5. Untuk membawa kerikil kasar kecepatan aliran sebesar $0,7 \mathrm{~m}^{3} /$ detik

6. Untuk membawa batu-batuan kecepatan aliran sebesar $1,2 \mathrm{~m}^{3} /$ detik.

Selain maksud tersebut perlu diingat bahwa dengan terbawa bendabenda di atas akan merusak dinding saluran. Untuk saluran yang terbuat dari semen kecepatan aliran tidak melebihi $1 \mathrm{~m} /$ detik.

\section{Beberapa Ketentuan Teknis}

Peta keadaan daerah yang lengkap dari suatu areal yang akan dilayani oleh suatu sistem pengelolaan air limbah dengan menggunakan saluran, mutlak diperlukan. Penggunaan skala yang sesuai penempatan garis kemiringan yang tepat adalah amat diperlukan untuk merencanakan pembuangan air limbah yang baik.

Penggunaan sistem grafitasi adalah pilihan yang tepat untuk mengalihkan air limbah, selain lebih ekonomis dan memudahkan untuk perluasan selanjutnya.

Apabila kita hendak melaksanakan pembuangan air limbah suatu perkotaan diperlukan untuk diketahui situasi umum daerah tersebut:

1. Sungai serta aliran, kolam, rawa, yang ada di wilayah,

2. Tinggi rendahnya tanah untuk mengetahui garis kemiringan wilayah,

3. Daerah yang terendam banjir,

4. Perencanaan jalan berikut rencana saluran, Pengaliran Air Limbah Di Daerah Pemukiman (Henita Rahmayanti, Dosen Jurusan Teknik Sipil FT- UNJ) 
5. Daerah yang terendam air saat hujan,

6. Kepadatan penduduk disetiap daerah,

7. Kepadatan bangunan disetiap daerah,

8. Ketinggian permukaan air tanah,

9. Arah pengaliran air sungai dan tinggi maksimum/minimum,

10. Jenis tanah yang ada,

11. Saluran listrik, telepon, serta gas dan riol yang sudah ada,

12. Kondisi kecuraman pantai.

Saluran yang biasa ada dalam masyarakat perkotaan terdiri dari dua macam saluran yaitu saluran tertutup dan saluran terbuka. Sebelum menentukan saluran mana yang dipergunakan untuk menyalurkan air limbah terlebih dahulu diperhitungkan keuntungan dan kerugian apabila menggunakan saluran terbuka dan saluran tertutup. Saluran terbuka hanya boleh dipergunakan apabila air telah melalui atau mengalami proses pengolahan. Selain itu hal yang perlu diperhatikan yaitu:

1. Selokan terletak pada tanah yang cukup luas,

2. Tidak ada kekhawatiran air limbah mendapat tambahan pengotoran dari luar,

3. Tidak banyak terdapat jembatan pada saluran air limbah,

4. Diperkirakan tidak banyak mengalami kerusakan atau gangguan dari luar.

Apabila keadaan di atas memungkinkan maka dianjurkan menggunakan saluran tertutup.

Saluran terbuka lebih disukai oleh masyarakat daripada saluran tertutup. Hal ini disebabkan ongkos pembuatan, pemeliharaan, pembersihan, dan pengawasan lebih murah. Selain itu saluran terbuka biasa dilengkapi dengan ruang cadangan untuk menghindari peluapan. Saluran terbuka umumnya ditempatkan ditepi jalan, seperti yang ada pada daerah pemukiman dikarenakan bila saluran ini ditempatkan dibelakang pekarangan rumah akan mengakibatkan hal-hal berikut:

1. Sulit melakukan pengawasan

2. Tidak dapat digunakan sebagai saluran pengeringan jalan

3. Memerlukan pagar pelindung untuk menghindari kecelakaan

4. Perlu diberi ganti rugi bagi pemilik tanah yang terkena saluran tersebut. 


\section{Perlengkapan yang Diperlukan dalam Pembuangan Air Limbah Saluran}

\section{Air Hujan}

Untuk mengurangi volume air yang akan dibuang dalam pipa pembuangan air limbah, maka air yang berasal dari air hujan sebaiknya dipisahkan dengan saluran tertutup/ pipa untuk pembuangan air limbah.

\section{Saluran Pipa Air Limbah}

Banyak macam bahan yang dipergunakan untuk penyaluran air limbah antara lain tanah liat, beton, asbestor semen, besi tuang serta jenis plastik.

\section{Pipa saluran rumah tangga}

Sebelum saluran rumah tangga digabungkan dengan saluran induk, hendaknya saluran ini memenuhi ketentuan antara lain:

1. Kemiringan saluran sebesar $1: 40$

2. Air limbah dalam saluran induk diusahakan tidak masuk kembali ke saluran sambungan karena mengganggu masuknya air.

3. Air limbah rumah tangga jangan sampai mengotori dinding pipa induk.

4. Setiap sambungan saluran air limbah rumah tangga dan induk dibuat lubang pemeriksaan.

\section{Penerapan Pengolahan Air Limbah di Masyarakat}

Apabila suatu kota telah mempunyai sistem pembuangan air limbah yang berupa saluran tertutup dengan pengolahan tersendiri, maka setiap air limbah dan kotoran rumah tangga yang dihasilkan akan dibuang ke saluran kota terdekat untuk dialirkan tempat pengelolaan yang tersedia. Akan tetapi, apabila kota itu belum memiliki sistem pembuangan air limbah secara tertutup maka umumnya air limbah yang berasal dari kamar mandi dan cuci saja yang dibuang ke saluran limbah kota, sedangkan kotoran yang berasal dari WC akan dibuang ke tempat pembuangan khusus yang dikenal sebagai septic tank.

Dengan demikian setiap rumah tangga mempunyai septic tank tersendiri, sedangkan air limbah dari WC saja yang dibuang kesaluran kota sehubungan dengan pembuangan limbah kotoran ini maka perlu kiranya dipertimbangkan akibat negatif yang akan ditimbulkan dari pembuangan tersebut.

Pengaliran Air Limbah Di Daerah Pemukiman (Henita Rahmayanti, Dosen Jurusan Teknik Sipil FT- UNJ) 


\section{Penutup}

Kotaran dari masyarakat dan rumah tangga dan juga yang berasal dari industri, air tanah, air permukaan, serta buangan lainnya merupakan hal yang bersifat kotoran umum. Air limbah yang paling banyak diproduksi dikota Jakarta adalah limbah rumah tangga. Air limbah terdiri dari $80 \%$ air dan $20 \%$ benda padat. Jika tidak dikelola dengan baik air limbah sangat berbahaya terhadap kesehatan manusia mengingat bahwa banyak penyakit yang dapat ditularkan melalui air limbah.

Dengan semakin banyaknya zat organik yang dibuang oleh rumah tangga maka setiap hari akan dihasilkan air limbah yang berupa bahan-bahan organik dalam jumlah yang sangat besar. Selama waktu tertentu maka air limbah mengalami pembusukan dari zat organik yang ada di dalamnya. Sebagai akibat selanjutnya adalah timbulnya bau hasil pengurangan zat organik yang sangat menusuk. Apabila air limbah mengandung gas karbondioksida yang agresif, maka mau tidak mau akan mempercepat proses terjadi karat pada benda yang terbuat dari besi. Dengan rusaknya benda tersebut maka biaya pemeliharaannya akan semakin besar, yang berarti menimbulkan kerugian material.

Disamping bau yang ditimbulkan, maka dengan menumpuknya ampas akan memerlukan tempat yang banyak dan mengganggu keindahan tempat disekitarnya.

Diperlukan suatu studi khusus mengenai pengelolaan yang sangat baik dalam mengelola air limbah sehingga tidak akan ada masalah yang dapat ditimbulkan dari limbah itu sendiri.

Perlu masyarakat mengetahui arti penting pengelolaan limbah yang baik dalam sistem drainase. Serta partisipasi dalam menjaga sistem drainase.

Kebijakan pemerintah dianggap perlu dalam pengelolaan air limbah yang nantinya dapat memperkecil masalah lingkungan hidup dalam bentuk perundang-undangan. 


\section{Daftar Pustaka}

Hindarko S, Drainase Kawasan Daerah, Esha, Jakarta, 2002.

Sugiharto, Dasar-dasar Pengelolaan Air Limbah, Penerbit Universitas Indonesia, Jakarta, 1987.

Rossalina, Nensi E V. Hidrolika Saluran Terbuka, Erlangga, Jakarta, 1992.

Pengaliran Air Limbah Di Daerah Pemukiman (Henita Rahmayanti, Dosen Jurusan Teknik Sipil FT- UNJ) 